\title{
Report seeks solutions for nitrate in drinking water
}

\begin{abstract}
$\Lambda$ new report by UC Davis researchers, commissioned by the California State Water Resources Control Board and released in mid-March, is
\end{abstract} the first comprehensive scientific investigation of nitrate contamination of drinking water in high-risk areas of California.

Titled "Addressing Nitrate in California's Drinking Water," the report defines the extent of the problem, recommends clean-up strategies and outlines possible funding mechanisms.

"Cleaning up nitrate in groundwater is a complex problem with no single solution," said Jay Lund, director of the Center for Watershed Sciences at UC Davis. "This report should help inform discussions among drinking water, waste discharge and agricultural interests, and local governments on this issue."

Nitrogen in organic and synthetic fertilizers has dramatically increased crop production in California. However, excess nitrate applied on the surface can over many decades seep into groundwater. Almost one in 10 people living the areas studied, among the state's most productive agriculturally, risk dangerous nitrate levels in their drinking water, which have been linked to some illnesses.

UC Davis scientists examined data from wastewater treatment plants, septic systems, parks, lawns, golf courses

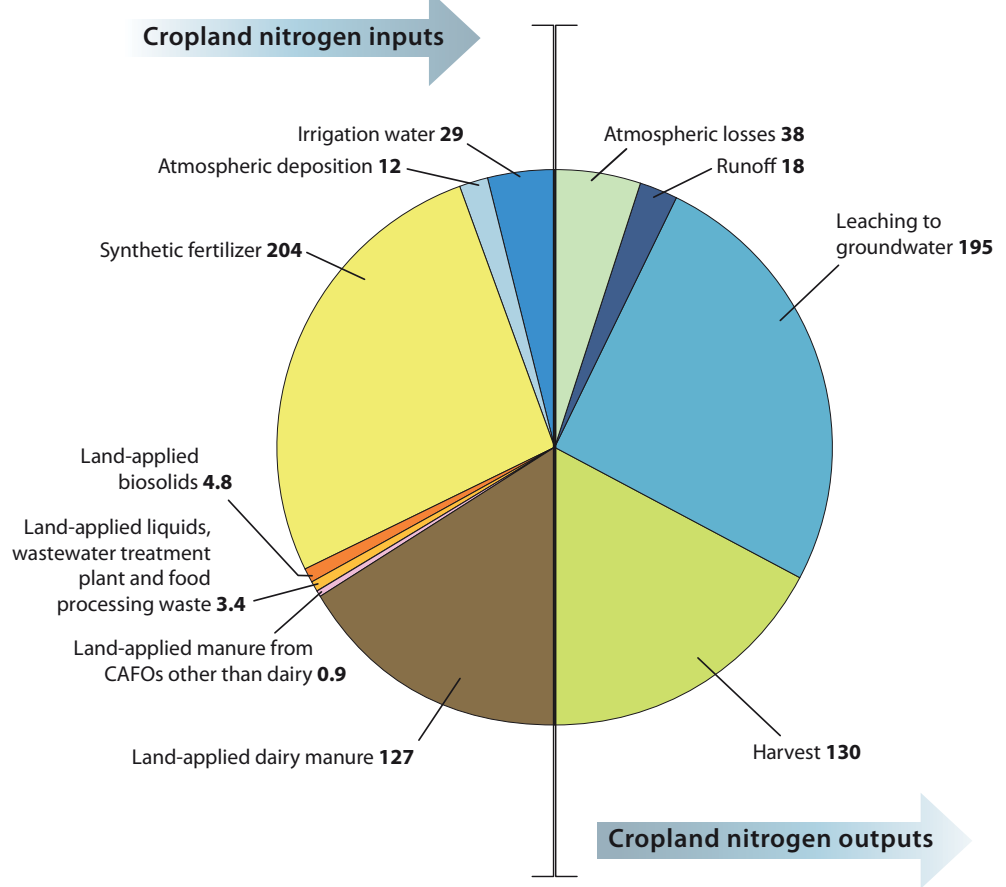

Cropland input and output of nitrogen (gigagram N/yr) in Tulare Lake Basin and Salinas Valley, 2005. The left side shows total N inputs to 3.12 million acres, not including alfalfa. The right side shows total $\mathrm{N}$ outputs with leaching to groundwater estimated by difference between known inputs and outputs. Source: Viers JH et al. 2012. Nitrogen Sources and Loading to Groundwater. Tech Rep 2 in: Addressing Nitrate in California's Drinking Water. UC Davis Center for Watershed Sciences. and farms in the Tulare Lake Basin and Salinas Valley, areas that include Fresno, Bakersfield and Salinas. Their report calls for a statewide effort to integrate water-related data collection by various state and local agencies.

Thomas Harter, UC Cooperative Extension specialist in the department of Land, Air, and Water Resources at UC Davis, said the report bolsters efforts by scientists with UC Agriculture and Natural Resources (ANR) to help growers manage nitrogen more effectively and, in turn, improve drinking water for future generations in the Tulare Lake Basin and Salinas Valley.

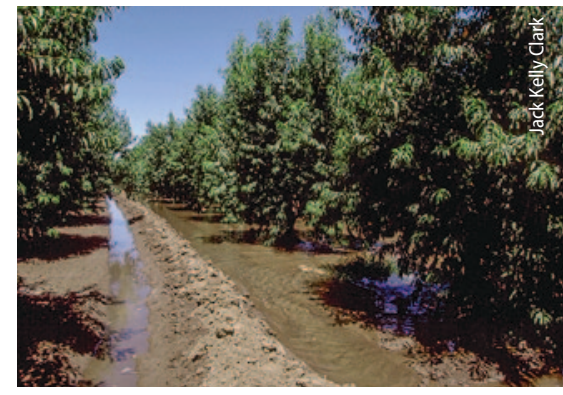

UC scientists are developing methods to reduce nitrate levels in irrigation runoff in order to farm more efficiently and protect drinking water in rural areas.
"This report defines the extent and costs of the problem, for the first time, and outlines how we can address it," said Harter, the report's lead author. "We hope it provides the foundation for informed policy discussions."

Scientists with ANR have been working to ensure that Californians have access to safe drinking water while the state's farmers can grow enough food to meet the world's increasing demand. Examples of related ANR research currently under way include:

- Best management practices to optimize water applications and minimize nitrate leaching in irrigated crops.

- A quick test to measure soil nitrate in the field so that growers can match fertilizer rates with plant needs.

- Nutrient planning tools that help dairy operators decide how to most efficiently manage manure applications to their silage crops.

- A new test, based on plant gene expression, that more accurately reflects the availability of nitrogen in the soil.

- The use of cover crops to prevent nitrates from moving out of crop fields and into groundwater.

- Adjustments to field length to reduce irrigation levels, and conservation tillage to help farmers better utilize nitrogen on dairies and in field crops (see page 55).

- Information and resources to enable dairy operators to comply with state and federal regulations.

\section{For more information:}

Addressing Nitrate in California's Drinking Water report http://groundwaternitrate.ucdavis.edu

ANR Healthy Crops, Safe Water http://ucanr.edu/News/Healthy_crops,_safe_water 